\title{
RASIONALISASI KONSEP EKONOMI DAN SOSIAL PADA PASAR MODAL TRADISIONAL
}

\author{
Bornok Situmorang ${ }^{1)}$, Emi Lestari ${ }^{2)}$ \\ ${ }^{1}$ Fakultas Bisnis, Universitas Universal Batam \\ bornoksitumorang@uvers.ac.id \\ ${ }^{2}$ Fakultas Bisnis, Universitas Universal Batam \\ emilestari@uvers.ac.id
}

\begin{abstract}
The history of moneylenders has long been recorded in the journey of Indonesian people in general and in almost all regions in particular. In the city of Batam, this phenomenon is increasingly thick in traditional markets, due to trading activities that occur every day and a very high cash circulation. This research was conducted in the traditional market of Nagoya Baru Jodoh, a sample of 42 respondents who dug up data on how traders make loans to moneylenders who have been around for years in the midst of traders. The research approach was carried out qualitatively by the survey method by distributing questionnaires containing 36 statements to measure traders' perceptions about the factors influencing considerations in credit application decisions. Then the data is processed using SPSS version 21 with descriptive and inductive statistics using multiple linear regression analysis and moderating variable analysis. The results of this study are that partially, irrational and rational considerations have a significant effect on the decision to submit credit with a significance value of 0,000 and 0.024 respectively, while simultaneously also a significant effect with a significance value of 0,000 . The moderating variable test shows a significance value of 0.146 or greater than 0.05 which means that the rational consideration factor has not been a barrier for traders to keep deciding on credit applications.
\end{abstract}

Keywords: Moneylenders; Traditional Capital Markets; Traditional Markets; Market Traders

\begin{abstract}
ABSTRAK
Sejarah rentenir sudah lama tercatat di dalam perjalanan masyarakat Indonesia pada umumnya dan hampir di seluruh daerah pada khususnya. Di Kota Batam, fenomena ini semakin kental terjadi di pasar tradisional, karena aktivitas perdagangan yang terjadi setiap hari serta perputaran uang kas yang sangat tinggi. Penelitian ini dilakukan di pasar tradisional Nagoya Baru Jodoh, jumlah sampel sebanyak 42 responden yang menggali data tentang bagaimana para pedagang melakukan peminjaman kepada rentenir yang sudah ada selama bertahun-tahun di tengah-tengah para pedagang. Pendekatan penelitian ini dilakukan dengan kualitatif dengan metode survei dengan menyebarkan kuesioner yang berisi 36 pernyataan untuk mengukur persepsi para pedagang tentang faktor-faktor yang mempengaruhi pertimbangan dalam keputusan pengajuan kredit. Kemudian data tersebut diolah dengan menggunakan SPSS versi 21 dengan statistik deskriptif dan induktif dengan menggunakan analisis regresi linear berganda serta analisis variabel moderasi. Adapun hasil penelitian ini adalah bahwa secara parsial, faktor-faktor pertimbangan irrasional maupun rasional berpengaruh signifikan terhadap keputusan pengajuan kredit dengan nilai signifikansi masing-masing 0,000 dan 0,024 sedangkan secara simultan juga berpengaruh signifikan dengan nilai signifikansi sebesar 0,000 . Uji variabel moderasi menunjukkan nilai signifikansi sebesar 0,146 atau lebih besar dari 0,05 yang berarti bahwa faktor pertimbangan rasional belum menjadi penghalang bagi para pedagang untuk tetap memutuskan pengajuan kredit.
\end{abstract}

Kata Kunci: Renteni; Pasar Modal Tradisional; Pasar Tradisional; Pedagang Pasar 


\section{PENDAhUluan}

Hal utama yang membuat bertumbuhnya rentenir adalah interaksi yang kuat dengan para nasabahnya termasuk dengan para pedagang di tengah-tengah pasar tradisional. (Susilawati, 2016). Menurut Anisa, ada interaksi sosial antar rentenir dengan pedagang muslim (al, 2017). Penelitian ini dilakukan pada pasar tradisional Nagoya baru Batam. Ada 3 (tiga) alasan utama yang menjadikan pasar tradisional sebagai tempatpertumbuhan yang sangat baik bagi rentenir, yaitu: interaksi sosial terjadi setiap hari, transaksi ekonomi terjadi setiap hari dan tingkat perputaran dan ketersediaan kas yang tinggi. Hal ini menimbulkan ketidakrasionalan di kalangan pedagang, dimana pertimbangan pedagang lebih memprioritaskan keuntungan yang bersifat jangka pendek dibandingkan dengan keuntungan yang bersifat jangka panjang. Penelitian yang dilakukan oleh Bornok Situmorang dan Emi Lestari, adapun pertimbangan utama pedagang untuk meminjam ke rentenir adalah karena mudah dan tidak bertele-tele pertimbangan itu adalah: Prosedur Penyaluran Kredit yang sederhana, Pelayanan yang terjadi setiap hari serta Lokasi yang dekat, karena rentenir berada dan tumbuh di tengah-tengah para pedagang dan berinteraksi setiap hari, serta tidak ada jaminan yaitu cukup dengan kepercayaan saja. Tetapi pertimbangan lain yang disadari oleh pedagang sebagai hal yang memberatkan jika dibanding dengan pengajuan kredit ke Lembaga Keuangan Formal adalah Tingkat Suku Bunga yang tinggi serta Jangka Waktu Peminjaman yang singkat pada umumnya harian (Situmorang, 2018). Ketidakrasionalan ini terlihat jelas pada pertimbangan pedagang yang lebih memprioritaskan pada keadaan saat pra (sebelum) meminjam dari pada pasca (setelah) meminjam. Prose peminjaman mudah, tapi proses pengembalian memberatkan. Atas dasar ini, Faktor Rasional adalah faktor-faktor yang mendorong pedagang untuk mengajukan kredit ke Lembaga Keuangan Formal, sedangkan Faktor Irrasional adalah faktor-faktor yang mendorong pedagang untuk mengajukan kredit ke Rentenir. Dengan melihat fenomena ini, maka perlu dilakukan penelitian tentang faktor-faktor yang dapat merasionalisasi pola pikir dan pola tindak para pedagang. Penelitian ini berawal dari fenomena yang marak terjadi di tengah-tengah masyarakat miskin yaitu peminjaman uang yang bersumber dari rentenir. Rentenir ini merupakan profesi yang sudah melembaga sehingga disebut juga sebagai Lembaga Keuangan pada Pasar Modal Tradisional (Kartono, 2004). Fenomena ini marak dimana-mana, seperti di lingkungan warga pesisir (Syafrini, 2014) juga di pasar-pasar tradisional (Hamka, 2010). Keberadaan rentenir ini sangat kontra produktif dengan kebijakan pemerintah yang ingin memajukan dan merevitalisasi pasar tradisional seperti diamanatkan dalam Undang-undang Nomor 7 tahun 2014 (Indonesia, Republik, 2014).

\section{KAJIAN LITERATUR}

\section{Rasionalisasi.}

Ada beberapa pengertian rasionaliasi yang dapat diterapkan pengertiannya pada penelitian ini. Rasionalisasi adalah proses, cara, perbuatan menjadikan bersifat rasional; proses, cara, perbuatan merasionalkan. Rasionalisasi adalah proses, cara, perbuatan yang rasional (menurut rasio) atau menjadikan nisbahnya patut (baik). Rasionalisasi adalah perbaikan dalam perusahaan dengan menghemat tenaga kerja dan biaya serta mempertinggi produksi; perbaikan nisbah antara berbagai komponen dalam perusahaan 
sehingga perusahaan menjadi sehat (Bahasa, 2016). Ketiga pengertian di atas merupakan pengertian menurut Kamus Besar Bahasa Indonesia yang relevan dengan penelitian ini.

\section{Konsep Ekonomi dan Sosial}

Penggabungan kata ekonomi dan sosial menciptakan suatu pengertian bahwa hubungan sosial dapat menciptakan aktivitas ekonomi serta motif ekonomi dapat terjadi di tengah-tengah hubungan sosial. Definisi (modal) sosial adalah jumlah sumber-sumber daya, aktual atau virtual (tersirat) yang berkembang pada seorang individu atau sekelompok individu karena kemampuan untuk memiliki suatu jaringan yang dapat bertahan lama dalam hubungan-hubungan yang lebih kurang telah diinstitusikan berdasarkan pengetahuan dan pengenalan timbal balik. Konsep definisi (modal) sosial lainnya yang sering digunakan adalah menurut Coleman dalam Yustika (2008) yang mendefinisak modal sosial menurut fungsinya yaitu modal sosial itu bukanlah entitas tunggal, tetapi entitas majemuk yang mengandung dua elemen. Pertama, modal sosial mencakup beberapa aspek dari struktur sosial. Kedua modal sosial memfasilitasi tindakan tertentu dari pelaku dalam struktur tersebut. (Y. Ahmad Erani, 2008)

\section{Rentenir sebagai Lembaga Keuangan pada Pasar Modal Tradisional}

Pengertian rentenir yang dapat dikutip dari KBBI (Kamus Besar Bahasa Indonesia) online, rentenir adalah orang yang mencari nafkah dengan membungakan uang; tukang riba; pelepas uang; lintah darat. Keberadaan rentenir sangat marak dan bertumbuh secara baik di tengahtengah pasar-pasar tradisional, hal ini dapat telihat secara langsung serta dibuktikan juga oleh penelitian-penelitian terdahulu. Seperti yang dilakukan oleh
Sumitro Djojohadikusumo (1989) yang menyimpulkan bahwa aktivitas pelepas uang yang hidup dalam masyarakat, merupakan profil dari praktik perkreditan yang dikelola secara individual yang tidak terorganisasi dan pada umumnya mempunyai pengaruh yang kurang baik terhadap peminjamnya (Djojohadikusumo, 1998) dan lain-lain. Rentenir sebagai salah satu bentuk pasar modal tradisional juga muncul sebagai fenomena sosial. Konsep rentenir ini mengalami berbagai variasi sehingga menimbulkan beberapa istilah, antara lain: Bank Thitil, Bank BKK, Koperasi Pasar dan istilah-istilah lain yang melembaga.

\section{Faktor-faktor Irasional}

Adapun faktor-faktor irasional dalam konteks penelitian ini adalah faktor-faktor yang memudahkan proses dan prosedur peminjaman tetapi memberatkan proses dan prosedur pengembalian antara lain: Prosedur Penyaluran Kredit (tidak bertele-tele), Pelayanan (interaksi sosial dan ekonomi terjadi setiap hari), Lokasi (beraktivitas dalam satu tempat yang sama/pasar) dan Jaminan (saling mengenal dan saling percaya). Prosedur Penyaluran Kredit merupakan langkah-langka yang harus diikuti oleh calon debitur untuk memperoleh persetujuan pemberian kredit dari kreditur. Pelayanan adalah aktivitas yang disediakan oleh pihak yang melayani terhadap pihak yang dilayani. Aktivitas ini akan menciptakan interaksi dan interaksi inilah yang difasilitasi oleh perusahaan pemberi layanan yang ukurannya bukan hanya ditentukan pada pihak yang melayani saja tetapi lebih banyak ditentukan oleh pihak yang dilayani, karena merekalah yang menikmati layanan sehingga dapat mengukur sesuai dengan harapan mereka. Lokasi yang dimaksud adalah lokasi lembaga keuangan baik formal maupun non formal. 
Dalam hal ini adalah tempat dimana diperjual belikannya produk perbankan dan lain-lain dan pusat pengendalian perbankan serta lembaga keuangan non bank, seperti yang ditulis oleh Kasmir (2004:163). Jaminan dalam hal ini jaminan kredit merupakan sumber pembayaran kedua. Dalam pengajuan kredit ke Bank atau lembaga keuangan formal lainnya, apabila karena berbagai hal debitur dinyatakan pailit dan tidak mampu membayar kembali kredit, harta debitur yang dijadikan jaminan akan di eksekusi, hasil penjualannya digunakan untuk membayar kembali kredit (Sutojo, 2000).

\section{Faktor-faktor Rasional}

Berdasarkan pengertian rasional yang dikutip dari KBBI, maka faktor-faktor rasional adalah faktor-faktor yang berdasarkan pikiran dan pertimbangan yang logis dan cocok dengan akal sehat manusia. Dalam konteks penelitian ini, rasional itu adalah lebih mempertimbangkan kemudahan-kemudahan yang akan diperoleh sesaat setelah melakukan peminjaman daripada sebelum melakukan peminjaman. Dengan kata lain lebih prosedur dan proses pengembalian daripada prosedur dan proses peminjaman. Dalam penelitian ini faktor-faktor yang rasional Tingkat Suku Bunga dan Waktu Pengembalian. Pengertian Tingkat Suku Bunga menurut Kasmir adalah balas jasa yang diberikan oleh bank yang berdasarkan prinsip konvensional kepada nasabah (Kasmir, 2014). Sedangkan Waktu Pengembalian merupakan jangka waktu yang disepakati oleh kedua belah pihak. Jangka waktu pengembalian pada rentenir biasanya harian dengan periode yang tidak lama, sedangkan jangka pengembalian waktu Lembaga Keuangan Formal adalah bulanan dengan periode yang fleksibel sesuai kemampuan peminjam.

\section{METODE PENELITIAN}

Pendekatan dalam penelitian ini dilakukan dengan kualitatif dengan metode survei serta menyebarkan kuesioner yang berisi pernyataan-pernyataan sebanyak 36 butir untuk mengukur persepsi para pedagang tentang faktor-faktor yang mempengaruhi pertimbangan dalam membuat keputusan pengajuan kredit (Moleong, 2007). Penelitian dilakukan pada pasar Nagoya Baru Batam, sampel diambil dengan metode Purposive Sampling,dengan kriteria:

- Seluruh pedagang tetap pada Pasar Nagoya Baru (460 pedagang)

- Pedagang tersebut mengetahui keberadaan rentenir dan pernah berinteraksi sosial dengan Rentenir (460 pedagang)

- Pedagang tersebut pernah mengajukan kredit kepada Rentenir (190 pedagang)

- Pedagang tersebut nasabah eksis yang sedang mempunyai hutang (kredit) kepada Rentenir (42 pedagang)

Teknik pengumpulan data yang dilakukan dalam penelitian ini adalah teknik kuesioner. Merupakan metode pengumpulan data yang dilakukan dalam rangka mengumpulkan data dengan cara membagi daftar pertanyaan kepada seluruh responden agar responden tersebut memberikan jawabannya. Tipe kuesioner yang digunakan adalah kuesioner tertutup yaitu jawaban sudah disediakan oleh peneliti sehingga responden tinggal memilih (Suliyanto, 2006). Teknik analisis data dilakukan dengan menggunakan Analisis Regresi Linear Berganda dengan persamaan $Y=\alpha+\beta 1 x 1+\beta 2 \times 2+\varepsilon$, dimana: $\mathrm{Y}=$ Keputusan Pengajuan Kredit $\alpha=$ konstanta.

$\beta=$ koefisien regresi.

$x 1=$ Faktor-faktor pertimbangan Irasional .

$x 2=$ faktor-faktor pertimbangan Rasional

$\varepsilon=$ error.

Serta Uji Variabel Pemoderasi dimana X2 yang disebut variabel pemoderasi. Variabel $\mathrm{X} 1$ dan X2 merupakan pengaruh langsung dari variabel X1 dan X2 terhadap Y.

\section{HASIL DAN PEMBAHASAN}

Adapun karakteristik responden ditunjukkan pada tabel berikut: 
Tabel 1 Presentase Jenis Kelamin Responden

\begin{tabular}{|l|l|l|}
\hline Jenis Kelamin & $\begin{array}{l}\text { Frekuensi } \\
\text { (responden) }\end{array}$ & Persentase (\%) \\
\hline Laki-laki & 19 & 45 \\
\hline Perempuan & 23 & 54 \\
\hline Jumlah & 42 & 100 \\
\hline
\end{tabular}

Berdasarkan Tabel 1 tersebut di atas, dari 42 responden terdapat 19 responden yang berjenis kelamin laki-laki dengan porsi sebesar $45 \%$ dan 23 responden berjenis kelamin perempuan dengan porsi sebesar 54\%. Dengan demikian, responden yang berjenis kelamin perempuan mendominasi, dibandingkan dengan responden yang berjenis kelamin laki-laki.

Tabel 2 Komposisi Usia Responden

\begin{tabular}{|c|c|c|}
\hline Usia & $\begin{array}{l}\text { Frekuensi } \\
\text { (responden) }\end{array}$ & Persentase (\%) \\
\hline$<30$ Tahun & 9 & 21 \\
\hline 30-40 Tahun & 20 & 48 \\
\hline$>40$ Tahun & 13 & 31 \\
\hline Jumlah & 42 & 100 \\
\hline
\end{tabular}

Berdasarkan tabel 2 di atas, usia responden paling banyak pada rentang usia 30-40 tahun, yaitu sebesar $48 \%$ dengan jumlah 20 responden, kemudian rentang usia di atas 40 tahun sebesar $31 \%$ dengan jumlah 13 responden dan rentang usia di bawah 30 tahun dengan jumlah 9 responden.

Tabel 3 Komposisi Pendidikan Terakhir Responden

\begin{tabular}{|l|c|c|}
\hline Pendidikan Terakhir & $\begin{array}{c}\text { Frekuensi } \\
\text { (responden) }\end{array}$ & Persentase (\%) \\
\hline SD & 9 & 21 \\
\hline SMP & 16 & 38 \\
\hline SMA & 17 & 41 \\
\hline Perguruan Tinggi & - & - \\
\hline Jumlah & 42 & 100 \\
\hline
\end{tabular}

Dari tabel 3 tersebut di atas, menunjukkan bahwa mayoritas responden memiliki pendidikan terakhir setingkat SMA sebanyak 17 responden atau sebesar $41 \%$, kemudian setingkat SMP sebanyak 16 orang atau sebesar $38 \%$ dan setingkat SD sebanyak 9 orang sebesar $21 \%$.

Tabel 4. Komposisi Status Responden

\begin{tabular}{|c|c|c|}
\hline Status & $\begin{array}{c}\text { Frekuensi } \\
\text { (responden) }\end{array}$ & $\begin{array}{c}\text { Persentase } \\
(\%)\end{array}$ \\
\hline Tidak Kawin (TK) & 5 & 12 \\
\hline Kawin /Anak 0 & 2 & 5 \\
\hline Kawin/ Anak 1 & 12 & 28 \\
\hline $\begin{array}{c}\text { Kawin/Anak 2 atau } \\
\text { lebih }\end{array}$ & 21 & 50 \\
\hline Janda/Duda & 2 & 5 \\
\hline Jumlah & 42 & 100 \\
\hline
\end{tabular}

Dari tabel 4 tersebut di atas, menunjukkan bahwa mayoritas responden memiliki status kawin dengan jumlah anak sebanyak dua atau lebih yaitu 21 responden atau sebesar 50\%. Sedangkan yang paling sedikit adalah menikah tidak (belum) memiliki anak serta janda masing masing 2 responden atau sebesar $5 \%$.

Tabel 5 Komposisi Lama Usaha Responden

\begin{tabular}{|l|c|c|}
\hline \multicolumn{1}{|c|}{ Lama Usaha } & Frekuensi (responden) & Persentase (\%) \\
\hline$<2$ tahun & 1 & 3 \\
\hline $2-5$ tahun & 11 & 26 \\
\hline $6-10$ tahun & 27 & 64 \\
\hline$>10$ tahun & 3 & 7 \\
\hline Jumlah & 42 & 100 \\
\hline
\end{tabular}

Dari tabel 5 tersebut di atas, menunjukkan bahwa mayoritas responden sudah menjalankan usahanya selama 6-10 tahun sebanyak 27 responden atau $64 \%$ dari jumlah seluruh responden. Sedangkan sisanya adalah 11 responden sudah melakukan usahanya selama 25 tahun atau sebesar 26\%, 3 responden sudah melakukan usahanya selama lebih dari 10 tahun atau sebesar $7 \%$ dan yang paling kecil adalah 1 responden menjalankan usahanya belum dua tahun atau sebesar $3 \%$.

Tabel 6 Komposisi Responden berdasarkan Penghasilan Rata-rata/bulan

\begin{tabular}{|c|c|c|}
\hline $\begin{array}{c}\text { Jumlah Penghasilan } \\
\text { rata-rata/bulan (Rp) }\end{array}$ & $\begin{array}{c}\text { Frekuensi } \\
\text { (responden) }\end{array}$ & Persentase (\%) \\
\hline$<3$ juta & 0 & 0 \\
\hline 4-5 Juta & 4 & 9 \\
\hline 6-10 juta & 36 & 86 \\
\hline$>10$ tahun & 2 & 5 \\
\hline Jumlah & 42 & 100 \\
\hline
\end{tabular}

Dari tabel 6 tersebut di atas, menunjukkan bahwa mayoritas responden memiliki penghasilan rata-rata perbulan Rp6.000.000,00 Rp10.000.000,00 perbulan dengan jumlah responden sebanyak 36 atau sebesar $86 \%$. Kemudian 4 responden memiliki penghasilan Rp4.000.000,00 - Rp5.000.000,00 atau sebesar 9\% dan sisanya memiliki penghasilan rata-rata perbulan di atas Rp10.000.000 yaitu 2 responden atau sebesar $5 \%$.

\section{Analisis Deskriptif}

Analisis ini bertujuan untuk menginformasikan nilai skor jawaban dan hasil persentase dari setiap pernyataan, beserta nilai perhitungan ratarata (mean) yang diperhitungkan dengan menggunakan SPSS versi 21. Hasil pengujian 
untuk variabel independen dan variabel dependen ditunjukkan pada tabel berikut ini

Tabel 7 Rekapitulasi deskripsi variabel independen: Pertimbangan Rasional (X1) dan Irasional (X2) serta Variabel Dependen: Keputusan Pengajuan Kredit (Y)

\begin{tabular}{|c|c|c|c|c|c|}
\hline \multirow[t]{3}{*}{ No } & Pernyataan & Tanggapan & $\ddot{\bar{\theta}}$ & 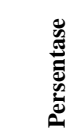 & $\begin{array}{l}\text { Rata } \\
\text {-rata }\end{array}$ \\
\hline & $\begin{array}{l}\text { PERTIMBANGA } \\
\text { N IRASIONAL } \\
\text { (X1) }\end{array}$ & & & & \\
\hline & $\begin{array}{l}\text { A. Pengajuan } \\
\text { Kredit tidak } \\
\text { Bertele-tele }\end{array}$ & & & & \\
\hline 1. & $\begin{array}{l}\text { Saya hanya } \\
\text { memilih } \\
\text { kredit/pinjaman } \\
\text { dengan syarat- } \\
\text { syarat yang mudah } \\
\text { dan tidak } \\
\text { merepotkan. }\end{array}$ & $\begin{array}{l}\text { 1. Sangat } \\
\text { tidak } \\
\quad \text { setuju } \\
\text { 2. Tidak } \\
\text { Setuju } \\
\text { 3. Netral } \\
\text { 4. Setuju } \\
\text { 5. Sangat } \\
\text { Setuju }\end{array}$ & $\begin{array}{l}0 \\
0 \\
0 \\
2 \\
10 \\
30\end{array}$ & $\begin{array}{l}0,00 \\
\\
0,00 \\
4,76 \\
23,81 \\
71,43\end{array}$ & 4,67 \\
\hline 2. & $\begin{array}{l}\text { Saya memutuskan } \\
\text { meminjam dengan } \\
\text { syarat-syarat yang } \\
\text { mudah saya } \\
\text { pahami. }\end{array}$ & $\begin{array}{l}\text { 1. Sangat } \\
\text { tidak } \\
\quad \text { setuju } \\
\text { 2. Tidak } \\
\text { Setuju } \\
\text { 3. Netral } \\
\text { 4. Setuju } \\
\text { 5. Sangat } \\
\text { Setuju }\end{array}$ & $\begin{array}{l}0 \\
\\
0 \\
2 \\
15 \\
25\end{array}$ & $\begin{array}{l}0,00 \\
0,00 \\
4,76 \\
35,71 \\
59,52\end{array}$ & 4,55 \\
\hline 3. & $\begin{array}{l}\text { Saya tidak punya } \\
\text { waktu yang banyak } \\
\text { untuk memenuhi } \\
\text { syarat-syarat } \\
\text { pengajuan } \\
\text { kredit/pinjaman. }\end{array}$ & $\begin{array}{l}\text { 1. Sangat } \\
\text { tidak } \\
\quad \text { setuju } \\
\text { 2. Tidak } \\
\text { Setuju } \\
\text { 3. Netral } \\
\text { 4. Setuju } \\
\text { 5. Sangat } \\
\text { Setuju }\end{array}$ & $\begin{array}{l}0 \\
0 \\
0 \\
2 \\
16 \\
24\end{array}$ & $\begin{array}{l}0,00 \\
0,00 \\
4,76 \\
38,10 \\
57,14\end{array}$ & 4,52 \\
\hline & $\begin{array}{l}\text { B. Intensitas } \\
\text { Interaksi sosial } \\
\text { dan ekonomi yang } \\
\text { tinggi. }\end{array}$ & & & & \\
\hline 4. & $\begin{array}{l}\text { Saya terbiasa } \\
\text { berinteraksi dengan } \\
\text { banyak orang yang } \\
\text { kemudian akan } \\
\text { berlanjut menjadi } \\
\text { transaksi jual beli. }\end{array}$ & $\begin{array}{l}\text { 1. Sangat } \\
\text { tidak } \\
\quad \text { setuju } \\
\text { 2. Tidak } \\
\text { Setuju } \\
\text { 3. Netral } \\
\text { 4. Setuju } \\
\text { 5. Sangat } \\
\text { Setuju }\end{array}$ & $\begin{array}{l}0 \\
0 \\
0 \\
3 \\
14 \\
25\end{array}$ & $\begin{array}{l}0,00 \\
\\
0,00 \\
7,14 \\
33,33 \\
59,52\end{array}$ & 4,52 \\
\hline 5. & $\begin{array}{l}\text { Saya akan } \\
\text { mengajukan } \\
\text { kredit/pinjaman } \\
\text { kepada pihak yang } \\
\text { lebih sering } \\
\text { berinteraksi atau } \\
\text { bertransaksi } \\
\text { dengan saya. }\end{array}$ & $\begin{array}{l}\text { 1. Sangat } \\
\text { tidak } \\
\quad \text { setuju } \\
\text { 2. Tidak } \\
\text { Setuju } \\
\text { 3. Netral } \\
\text { 4. Setuju } \\
\text { 5. Sangat } \\
\text { Setuju }\end{array}$ & $\begin{array}{l}0 \\
0 \\
0 \\
2 \\
17 \\
23\end{array}$ & $\begin{array}{l}0,00 \\
\\
0,00 \\
4,76 \\
40,48 \\
54,76\end{array}$ & 4,50 \\
\hline 6. & $\begin{array}{l}\text { Saya lebih memilih } \\
\text { untuk meminjam di } \\
\text { sela-sela } \\
\text { perbincangan } \\
\text { kapan saja di saat } \\
\text { saya } \\
\text { membutuhkannya. }\end{array}$ & $\begin{array}{l}\text { 1. Sangat } \\
\text { tidak } \\
\quad \text { setuju } \\
\text { 2. Tidak } \\
\text { Setuju } \\
\text { 3. Netral } \\
\text { 4. Setuju } \\
\text { 5. Sangat } \\
\text { Setuju }\end{array}$ & $\begin{array}{l}0 \\
0 \\
0 \\
2 \\
14 \\
26\end{array}$ & $\begin{array}{l}0,00 \\
\\
0,00 \\
4,76 \\
33,33 \\
61,90\end{array}$ & 4,57 \\
\hline & $\begin{array}{l}\text { C. Melakukan } \\
\text { kegiatan sehari- } \\
\text { hari di lokasi yang } \\
\text { sama (pasar) }\end{array}$ & & & & \\
\hline
\end{tabular}

\begin{tabular}{|c|c|c|c|c|c|}
\hline 7. & $\begin{array}{l}\text { Saya lebih memilih } \\
\text { untuk meminjam } \\
\text { kepada pihak yang } \\
\text { sehari-hari berada } \\
\text { di sekitar saya. }\end{array}$ & $\begin{array}{l}\text { 1. Sangat } \\
\text { tidak } \\
\quad \text { setuju } \\
\text { 2. Tidak } \\
\text { Setuju } \\
\text { 3. Netral } \\
\text { 4. Setuju } \\
\text { 5. Sangat } \\
\text { Setuju }\end{array}$ & $\begin{array}{l}0 \\
\\
0 \\
4 \\
14 \\
24\end{array}$ & $\begin{array}{l}0,00 \\
0,00 \\
9,52 \\
33,33 \\
57,14\end{array}$ & 4,48 \\
\hline 8. & $\begin{array}{l}\text { Saya menghindari } \\
\text { kredit/pinjaman } \\
\text { yang } \\
\text { mengharuskan saya } \\
\text { mendatangi tempat } \\
\text { kreditur. }\end{array}$ & $\begin{array}{l}\text { 1. Sangat } \\
\text { tidak } \\
\quad \text { setuju } \\
\text { 2. Tidak } \\
\text { Setuju } \\
\text { 3. Netral } \\
\text { 4. Setuju } \\
\text { 5. Sangat } \\
\text { Setuju }\end{array}$ & $\begin{array}{l}0 \\
0 \\
2 \\
17 \\
23\end{array}$ & $\begin{array}{l}0,00 \\
0,00 \\
4,76 \\
40,48 \\
54,76\end{array}$ & 4,50 \\
\hline 9. & $\begin{array}{l}\text { Saya sangat } \\
\text { terbantu jika proses } \\
\text { pemberian dan } \\
\text { pengembalian } \\
\text { pinjaman saya } \\
\text { dilakukan di pasar } \\
\text { tempat saya } \\
\text { berjualan. }\end{array}$ & $\begin{array}{l}\text { 1. Sangat } \\
\text { tidak } \\
\quad \text { setuju } \\
\text { 2. Tidak } \\
\text { Setuju } \\
\text { 3. Netral } \\
\text { 4. Setuju } \\
\text { 5. Sangat } \\
\text { Setuju } \\
\end{array}$ & $\begin{array}{l}0 \\
0 \\
6 \\
12 \\
24\end{array}$ & $\begin{array}{l}0,00 \\
0,00 \\
14,29 \\
28,57 \\
57,14\end{array}$ & 4,43 \\
\hline & $\begin{array}{l}\text { D. Saling } \\
\text { mengenal dan } \\
\text { saling percaya }\end{array}$ & & & & \\
\hline 10 & $\begin{array}{l}\text { Saya lebih memilih } \\
\text { mengajukan } \\
\text { kredit/pinjaman } \\
\text { kepada pihak yang } \\
\text { saya kenal. }\end{array}$ & $\begin{array}{l}\text { 1. Sangat } \\
\text { tidak } \\
\quad \text { setuju } \\
\text { 2. Tidak } \\
\text { Setuju } \\
\text { 3. Netral } \\
\text { 4. Setuju } \\
\text { 5. Sangat } \\
\text { Setuju }\end{array}$ & $\begin{array}{l}0 \\
0 \\
4 \\
13 \\
25\end{array}$ & $\begin{array}{l}0,00 \\
0,00 \\
9,52 \\
30,95 \\
59,52\end{array}$ & 4,50 \\
\hline 11 & $\begin{array}{l}\text { Saya cukup } \\
\text { meminjam kepada } \\
\text { pihak yang sudah } \\
\text { saya percayai. }\end{array}$ & $\begin{array}{l}\text { 1. Sangat } \\
\text { tidak } \\
\quad \text { setuju } \\
\text { 2. Tidak } \\
\text { Setuju } \\
\text { 3. Netral } \\
\text { 4. Setuju } \\
\text { 5. Sangat } \\
\text { Setuju }\end{array}$ & $\begin{array}{l}0 \\
\\
0 \\
3 \\
18 \\
21\end{array}$ & $\begin{array}{l}0,00 \\
0,00 \\
7,14 \\
42,86 \\
50,00\end{array}$ & 4,43 \\
\hline 12 & $\begin{array}{l}\text { Saling mengenal } \\
\text { dan saling percaya } \\
\text { akan membuat saya } \\
\text { nyaman } \\
\text { mengajukan kredit }\end{array}$ & $\begin{array}{l}\text { 1. Sangat } \\
\text { tidak } \\
\quad \text { setuju } \\
\text { 2. Tidak } \\
\text { Setuju } \\
\text { 3. Netral } \\
\text { 4. Setuju } \\
\text { 5. Sangat } \\
\text { Setuju }\end{array}$ & $\begin{array}{l}0 \\
0 \\
11 \\
7 \\
24\end{array}$ & $\begin{array}{l}0,00 \\
0,00 \\
26,19 \\
16,67 \\
57,14\end{array}$ & 4,31 \\
\hline & $\begin{array}{l}\text { PERTIMBANGA } \\
\text { N RASIONAL } \\
\text { (X2) }\end{array}$ & & & & \\
\hline & $\begin{array}{l}\text { A. Tingkat Suku } \\
\text { Bunga }\end{array}$ & & & & \\
\hline 13 & $\begin{array}{l}\text { Besarnya bunga } \\
\text { pinjaman dari } \\
\text { kreditur dijelaskan } \\
\text { secara detail }\end{array}$ & $\begin{array}{l}\text { 1. Sangat } \\
\text { tidak } \\
\quad \text { setuju } \\
\text { 2. Tidak } \\
\text { Setuju } \\
\text { 3. Netral } \\
\text { 4. Setuju } \\
\text { 5. Sangat } \\
\text { Setuju }\end{array}$ & $\begin{array}{l}31 \\
10 \\
1 \\
0 \\
0\end{array}$ & $\begin{array}{l}73,81 \\
23,81 \\
2,38 \\
0,00 \\
0,00\end{array}$ & 1,29 \\
\hline 14 & $\begin{array}{l}\text { Saya dapat } \\
\text { menghitung berapa } \\
\text { besarnya bunga } \\
\text { pinjaman dari } \\
\text { kreditur }\end{array}$ & $\begin{array}{l}\text { 1. Sangat } \\
\text { tidak } \\
\quad \text { setuju } \\
\text { 2. Tidak } \\
\text { Setuju } \\
\text { 3. Netral } \\
\text { 4. Setuju } \\
\text { 5. Sangat } \\
\text { Setuju }\end{array}$ & $\begin{array}{l}17 \\
14 \\
11 \\
0 \\
0\end{array}$ & $\begin{array}{l}40,48 \\
33,33 \\
26,19 \\
0,00 \\
0,00\end{array}$ & 1,86 \\
\hline 15 & $\begin{array}{l}\text { Bunga pinjaman } \\
\text { sangat } \\
\text { memberatkan saya }\end{array}$ & $\begin{array}{l}\text { 1. Sangat } \\
\text { tidak } \\
\quad \text { setuju } \\
\text { 2. Tidak } \\
\text { Setuju } \\
\text { 3. Netral } \\
\text { 4. Setuju } \\
\text { 5. Sangat } \\
\text { Setuju }\end{array}$ & $\begin{array}{l}28 \\
10 \\
4 \\
0 \\
0\end{array}$ & $\begin{array}{l}66,67 \\
23,81 \\
9,52 \\
0,00 \\
0,00\end{array}$ & 1,43 \\
\hline
\end{tabular}




\begin{tabular}{|c|c|c|c|c|c|}
\hline 16 & $\begin{array}{l}\text { Bunga pinjaman } \\
\text { merupakan biaya } \\
\text { yang harus } \\
\text { ditanggung oleh } \\
\text { peminjam sehingga } \\
\text { perlu dijelaskan } \\
\text { dengan detail. }\end{array}$ & $\begin{array}{l}\text { 1. Sangat } \\
\text { tidak } \\
\quad \text { setuju } \\
\text { 2. Tidak } \\
\text { Setuju } \\
\text { 3. Netral } \\
\text { 4. Setuju } \\
\text { 5. Sangat } \\
\text { Setuju }\end{array}$ & $\begin{array}{l}26 \\
11 \\
5 \\
0 \\
0\end{array}$ & $\begin{array}{l}61,90 \\
26,19 \\
11,90 \\
0,00 \\
0,00\end{array}$ & 1,50 \\
\hline 17 & $\begin{array}{l}\text { Bunga pinjaman } \\
\text { mengurangi } \\
\text { keuntungan } \\
\text { penjualan saya }\end{array}$ & $\begin{array}{l}\text { 1. Sangat } \\
\text { tidak } \\
\quad \text { setuju } \\
\text { 2. Tidak } \\
\text { Setuju } \\
\text { 3. Netral } \\
\text { 4. Setuju } \\
\text { 5. Sangat } \\
\text { Setuju }\end{array}$ & $\begin{array}{l}28 \\
9 \\
5 \\
0 \\
0\end{array}$ & $\begin{array}{l}66,67 \\
21,43 \\
11,90 \\
0,00 \\
0,00\end{array}$ & 1,45 \\
\hline 18 & $\begin{array}{l}\text { Besarnya bunga } \\
\text { pinjaman membuat } \\
\text { saya tidak sanggup } \\
\text { mengembalikan } \\
\text { pinjaman. }\end{array}$ & $\begin{array}{l}\text { 1. Sangat } \\
\text { tidak } \\
\quad \quad \text { setuju } \\
\text { 2. Tidak } \\
\text { Setuju } \\
\text { 3. Netral } \\
\text { 4. Setuju } \\
\text { 5. Sangat } \\
\text { Setuju }\end{array}$ & $\begin{array}{l}7 \\
28 \\
7 \\
0 \\
0\end{array}$ & $\begin{array}{l}16,67 \\
66,67 \\
16,67 \\
0,00 \\
0,00\end{array}$ & 2 \\
\hline & B. Jangka Waktu & & & & \\
\hline 19 & $\begin{array}{l}\text { Saya keberatan } \\
\text { dengan jangka } \\
\text { waktu } \\
\text { pengembalian } \\
\text { pinjaman yang } \\
\text { singkat. }\end{array}$ & $\begin{array}{l}\text { 1. Sangat } \\
\text { tidak } \\
\quad \quad \text { setuju } \\
\text { 2. Tidak } \\
\text { Setuju } \\
\text { 3. Netral } \\
\text { 4. Setuju } \\
\text { 5. Sangat } \\
\text { Setuju }\end{array}$ & $\begin{array}{l}25 \\
13 \\
4 \\
0 \\
0\end{array}$ & $\begin{array}{l}59,52 \\
30,95 \\
9,52 \\
0,00 \\
0,00\end{array}$ & 1,50 \\
\hline 20 & $\begin{array}{l}\text { Saya keberatan } \\
\text { pengembalian } \\
\text { pinjaman dilakukan } \\
\text { setiap hari. }\end{array}$ & $\begin{array}{l}\text { 1. Sangat } \\
\text { tidak } \\
\quad \text { setuju } \\
\text { 2. Tidak } \\
\text { Setuju } \\
\text { 3. Netral } \\
\text { 4. Setuju } \\
\text { 5. Sangat } \\
\text { Setuju }\end{array}$ & $\begin{array}{l}20 \\
18 \\
4 \\
0 \\
0\end{array}$ & $\begin{array}{l}47,62 \\
42,86 \\
9,52 \\
0,00 \\
0,00\end{array}$ & 1,62 \\
\hline 21 & $\begin{array}{l}\text { Kegiatan usaha } \\
\text { saya terganggu } \\
\text { dengan adanya } \\
\text { pengembalian } \\
\text { pinjaman setiap } \\
\text { hari. }\end{array}$ & $\begin{array}{l}\text { 1. Sangat } \\
\text { tidak } \\
\quad \text { setuju } \\
\text { 2. Tidak } \\
\text { Setuju } \\
\text { 3. Netral } \\
\text { 4. Setuju } \\
\text { 5. Sangat } \\
\text { Setuju }\end{array}$ & $\begin{array}{l}27 \\
12 \\
3 \\
0 \\
0\end{array}$ & $\begin{array}{l}64,29 \\
28,57 \\
7,14 \\
0,00 \\
0,00\end{array}$ & 1,43 \\
\hline 22 & $\begin{array}{l}\text { Saya tidak sanggup } \\
\text { mengembalikan } \\
\text { pinjaman dalam } \\
\text { waktu yang } \\
\text { singkat. }\end{array}$ & $\begin{array}{l}\text { 1. Sangat } \\
\text { tidak } \\
\quad \text { setuju } \\
\text { 2. Tidak } \\
\text { Setuju } \\
\text { 3. Netral } \\
\text { 4. Setuju } \\
\text { 5. Sangat } \\
\text { Setuju }\end{array}$ & $\begin{array}{l}20 \\
18 \\
4 \\
0 \\
0\end{array}$ & $\begin{array}{l}47,62 \\
42,86 \\
9,52 \\
0,00 \\
0,00\end{array}$ & 1,62 \\
\hline 23 & $\begin{array}{l}\text { Saya memahami } \\
\text { perbedaan jangka } \\
\text { waktu/periode } \\
\text { angsuran seperti } \\
\text { harian, mingguan } \\
\text { dan bulanan }\end{array}$ & $\begin{array}{l}\text { 1. Sangat } \\
\text { tidak } \\
\quad \text { setuju } \\
\text { 2. Tidak } \\
\text { Setuju } \\
\text { 3. Netral } \\
\text { 4. Setuju } \\
\text { 5. Sangat } \\
\text { Setuju }\end{array}$ & $\begin{array}{l}26 \\
11 \\
5 \\
0 \\
0\end{array}$ & $\begin{array}{l}61,90 \\
26,19 \\
11,90 \\
0,00 \\
0,00\end{array}$ & 1,50 \\
\hline 24 & $\begin{array}{l}\text { Saya selalu } \\
\text { mempertimbangka } \\
\mathrm{n} \text { untuk memilih } \\
\text { periode } \\
\text { pengembalian } \\
\text { pinjaman seperti } \\
\text { harian, mingguan } \\
\text { dan bulanan. }\end{array}$ & $\begin{array}{l}\text { 1. Sangat } \\
\text { tidak } \\
\quad \text { setuju } \\
\text { 2. Tidak } \\
\text { Setuju } \\
\text { 3. Netral } \\
\text { 4. Setuju } \\
\text { 5. Sangat } \\
\text { Setuju }\end{array}$ & $\begin{array}{l}28 \\
10 \\
4 \\
0 \\
0\end{array}$ & $\begin{array}{l}66,67 \\
23,81 \\
9,52 \\
0,00 \\
0,00\end{array}$ & 1,43 \\
\hline & $\begin{array}{l}\text { KEPUTUSAN } \\
\text { PENGAJUAN } \\
\text { KREDIT (Y) }\end{array}$ & & & & \\
\hline
\end{tabular}

\begin{tabular}{|c|c|c|c|c|c|}
\hline 25 & $\begin{array}{l}\text { Saya tidak kuatir } \\
\text { mengajukan } \\
\text { pinjaman karena } \\
\text { saya mempunyai } \\
\text { penghasilan yang } \\
\text { jelas }\end{array}$ & $\begin{array}{l}\text { 1. Sangat } \\
\text { tidak } \\
\quad \text { setuju } \\
\text { 2. Tidak } \\
\text { Setuju } \\
\text { 3. Netral } \\
\text { 4. Setuju } \\
\text { 5. Sangat } \\
\text { Setuju }\end{array}$ & $\begin{array}{l}0 \\
0 \\
2 \\
19 \\
21\end{array}$ & $\begin{array}{l}0,00 \\
0,00 \\
4,76 \\
45,24 \\
50,00\end{array}$ & 4,45 \\
\hline 26 & $\begin{array}{l}\text { Saat mengajukan } \\
\text { pinjaman, saya } \\
\text { mempertimbangka } \\
\text { n kebutuhan saya. }\end{array}$ & $\begin{array}{l}\text { 1. Sangat } \\
\text { tidak } \\
\quad \text { setuju } \\
\text { 2. Tidak } \\
\text { Setuju } \\
\text { 3. Netral } \\
\text { 4. Setuju } \\
\text { 5. Sangat } \\
\text { Setuju }\end{array}$ & $\begin{array}{l}0 \\
0 \\
10 \\
13 \\
19\end{array}$ & $\begin{array}{l}0,00 \\
0,00 \\
23,81 \\
30,95 \\
45,24\end{array}$ & 4,21 \\
\hline 27 & $\begin{array}{l}\text { Jumlah pinjaman } \\
\text { yang saya ajukan } \\
\text { masih dalam batas } \\
\text { kemampuan saya } \\
\text { untuk } \\
\text { mengembalikannya } \\
\text {. }\end{array}$ & $\begin{array}{l}\text { 1. Sangat } \\
\text { tidak } \\
\quad \text { setuju } \\
\text { 2. Tidak } \\
\text { Setuju } \\
\text { 3. Netral } \\
\text { 4. Setuju } \\
\text { 5. Sangat } \\
\text { Setuju }\end{array}$ & $\begin{array}{l}0 \\
0 \\
0 \\
3 \\
21 \\
18\end{array}$ & $\begin{array}{l}0,00 \\
0,00 \\
7,17 \\
50,00 \\
42,86\end{array}$ & 4,36 \\
\hline 28 & $\begin{array}{l}\text { Sebelum } \\
\text { melakukan } \\
\text { peminjaman, saya } \\
\text { sudah } \\
\text { mempertimbangka } \\
\text { nnya terlebih } \\
\text { dahulu. }\end{array}$ & $\begin{array}{l}\text { 1. Sangat } \\
\text { tidak } \\
\quad \text { setuju } \\
\text { 2. Tidak } \\
\text { Setuju } \\
\text { 3. Netral } \\
\text { 4. Setuju } \\
\text { 5. Sangat } \\
\text { Setuju }\end{array}$ & $\begin{array}{l}0 \\
0 \\
2 \\
17 \\
23\end{array}$ & $\begin{array}{l}0,00 \\
0,00 \\
4,76 \\
40,48 \\
54,76\end{array}$ & 4,50 \\
\hline 29 & $\begin{array}{l}\text { Saya sudah sering } \\
\text { berhasil melunasi } \\
\text { pinjaman sampai } \\
\text { lunas }\end{array}$ & $\begin{array}{l}\text { 1. Sangat } \\
\text { tidak } \\
\quad \text { setuju } \\
\text { 2. Tidak } \\
\text { Setuju } \\
\text { 3. Netral } \\
\text { 4. Setuju } \\
\text { 5. Sangat } \\
\text { Setuju }\end{array}$ & $\begin{array}{l}0 \\
0 \\
0 \\
3 \\
14 \\
25\end{array}$ & $\begin{array}{l}0,00 \\
0,00 \\
7,14 \\
33,33 \\
59,52\end{array}$ & 4,57 \\
\hline 30 & $\begin{array}{l}\text { Saya sudah terbiasa } \\
\text { melakukan } \\
\text { pinjaman kepada } \\
\text { orang tertentu saja. }\end{array}$ & $\begin{array}{l}\text { 1. Sangat } \\
\text { tidak } \\
\quad \text { setuju } \\
\text { 2. Tidak } \\
\text { Setuju } \\
\text { 3. Netral } \\
\text { 4. Setuju } \\
\text { 5. Sangat } \\
\text { Setuju }\end{array}$ & $\begin{array}{l}0 \\
0 \\
4 \\
14 \\
24\end{array}$ & $\begin{array}{l}0,00 \\
0,00 \\
9,52 \\
33,33 \\
57,14\end{array}$ & 4,48 \\
\hline 31 & $\begin{array}{l}\text { Saya merasa puas } \\
\text { di saat berhasil } \\
\text { melunasi pinjaman. }\end{array}$ & $\begin{array}{l}\text { 1. Sangat } \\
\text { tidak } \\
\quad \text { setuju } \\
\text { 2. Tidak } \\
\text { Setuju } \\
\text { 3. Netral } \\
\text { 4. Setuju } \\
\text { 5. Sangat } \\
\text { Setuju }\end{array}$ & $\begin{array}{l}0 \\
0 \\
0 \\
2 \\
17 \\
23\end{array}$ & $\begin{array}{l}0,00 \\
0,00 \\
4,76 \\
40,48 \\
54,76\end{array}$ & 4,50 \\
\hline 32 & $\begin{array}{l}\text { Saya tidak } \\
\text { keberatan untuk } \\
\text { terus meminjam } \\
\text { pada saat saya } \\
\text { membutuhkannya. }\end{array}$ & $\begin{array}{l}\text { 1. Sangat } \\
\text { tidak } \\
\quad \text { setuju } \\
\text { 2. Tidak } \\
\text { Setuju } \\
\text { 3. Netral } \\
\text { 4. Setuju } \\
\text { 5. Sangat } \\
\text { Setuju }\end{array}$ & $\begin{array}{l}0 \\
0 \\
0 \\
6 \\
12 \\
24\end{array}$ & $\begin{array}{l}0,00 \\
0,00 \\
14,29 \\
28,57 \\
57,14\end{array}$ & 4,43 \\
\hline 33 & $\begin{array}{l}\text { Saya akan berusaha } \\
\text { untuk membayar } \\
\text { pinjaman sampai } \\
\text { lunas. }\end{array}$ & $\begin{array}{l}\text { 1. Sangat } \\
\text { tidak } \\
\quad \text { setuju } \\
\text { 2. Tidak } \\
\text { Setuju } \\
\text { 3. Netral } \\
\text { 4. Setuju } \\
\text { 5. Sangat } \\
\text { Setuju }\end{array}$ & $\begin{array}{l}0 \\
0 \\
4 \\
13 \\
25\end{array}$ & $\begin{array}{l}0,00 \\
0,00 \\
9,52 \\
30,95 \\
59,52\end{array}$ & 4,50 \\
\hline 34 & $\begin{array}{l}\text { Saya merasa } \\
\text { senang jika } \\
\text { dipercayai } \\
\text { meminjam } \\
\text { sejumlah uang. }\end{array}$ & $\begin{array}{l}\text { 1. Sangat } \\
\text { tidak } \\
\quad \text { setuju } \\
\text { 2. Tidak } \\
\text { Setuju } \\
\text { 3. Netral } \\
\text { 4. Setuju } \\
\text { 5. Sangat }\end{array}$ & $\begin{array}{l}0 \\
0 \\
3 \\
18 \\
21\end{array}$ & $\begin{array}{l}0,00 \\
0,00 \\
7,14 \\
42,86 \\
50,00\end{array}$ & 4,43 \\
\hline
\end{tabular}




\begin{tabular}{|c|c|c|c|c|c|}
\hline & & Setuju & & & \\
\hline 35 & $\begin{array}{l}\text { Saya selalu } \\
\text { berusaha menjaga } \\
\text { kepercayaan orang } \\
\text { yang meminjamkan } \\
\text { uang kepada saya. }\end{array}$ & $\begin{array}{l}\text { 1. Sangat } \\
\text { tidak } \\
\quad \text { setuju } \\
\text { 2. Tidak } \\
\text { Setuju } \\
\text { 3. Netral } \\
\text { 4. Setuju } \\
\text { 5. Sangat } \\
\text { Setuju }\end{array}$ & $\begin{array}{l}0 \\
11 \\
7 \\
24\end{array}$ & $\begin{array}{l}0,00 \\
0,00 \\
26,19 \\
16,67 \\
57,14\end{array}$ & 4,31 \\
\hline
\end{tabular}

Berdasarkan tabel 7 di atas, dapat dijelaskan:

Pertimbangan Irasional yang paling sering digunakan oleh para pedagang adalah:

Pengajuan Kredit yang tidak bertele-tele, dimana para pedagang pada umumnya sepakat bahwa mereka sangat mengharapkan adanya syarat pemberian kredit yang tidak bertele-tele, hal ini terlihat pada skor jawaban untuk Pernyataan pertama sampai pernyataan ke-3 cenderung menjawab Sangat Setuju dengan persentase di atas 50\%. Rata-rata tertinggi adalah pernyataan pertama sebesar 4,67.

Intensitas Interaksi sosial dan ekonomi yang tinggi, dimana para pedagang pada umumnya sepakat bahwa mereka mengakui seringnya interaksi sosial dan ekonomi dapat menumbuhkan niat untuk melanjutkan interaksi tersebut ke transaksi pinjaman sejumlah dana,hal ini terlihat pada skor jawaban pernyataan ke-4 sampai pernyatan ke-6 yang menjawab Sangat Setuju selalu di atas 50\% bahkan pernyataan 6 menunjukkan persentase $61,90 \%$. Rata-rata tertinggi adalah pada pernyataan ke-6 sebesar 4,57.

Melakukan kegiatan sehari-hari di lokasi yang sama (pasar), dalam hal ini para pedagang mengakui jika pertemuan atau tatap muka dalam satu lokasi yang sama secara intens dapat menambah niat untuk melakukan transaksi ekonomi dan keuangan seperti pengajuan dan pemberian kredit. Hal ini terlihat pada skor jawaban pernyataan ke-7 sampai pernyataan ke9 dimana lebih dari 50\% responden menjawab Sangat Setuju. Sedangkan rata-rata tertinggi adalah pada pernyataan ke-8 sebesar 4,50.

Saling mengenal dan saling percaya, faktor ini menjadi salah satu pertimbangan para pedagang untuk melakukan pinjaman kredit kepada kreditur, dalam hal ini jika sudah timbul keadaan saling mengenal dan saling percaya, maka para pedagang akan semakin yakin untuk melakukan pinjaman kredit yang dibutuhkan. Hal ini dapat dilihat pada jawaban pada ketiga pernyataan (pernyataan ke-10 sampai pernyataan ke-12) dengan jawaban Sangat Setuju sebesar $50 \%$ atau lebih. Rata-rata tertinggi adalah pernyataan ke-10 sebesar 4,50.

Pertimbangan rasional yang masih belum dipahami dan dijadikan sebagai alasan dalam mengajukan kredit antara lain:

Tingkat suku bunga, dalam hal ini tingkat suku bunga masih sering diabaikan dalam pengajuan kredit kepada kreditur, hal ini dapat dilihat pada beberapa pernyataan yang dijawab oleh para responden. Pernyataan ke-13, ke-15, ke-16, dan ke-17 pada umumnya dijawab Sangat tidak Setuju sebanyak di atas $50 \%$ oleh para responden. Sedangkan pernyataan ke-14, jawaban Sangat tidak Setuju sebanyak 40,43\% masih dominan dibandingkan jawaban lainnya. Pernyataan ke-18, pada umumnya dijawab Tidak Setuju oleh Responden dengan besaran $66,67 \%$. Indikator-indikator mengenai Tingkat Suku Bunga ini belum menjadi sesuatu hal yang cukup dipertimbangkan oleh para pedagang dalam mengajukan kreditnya. Rata-rata yang paling rendah adalah pada pernyataan ke-13 sebesar 1,29.

Jangka waktu, dalam hal ini berkaitan dengan frekuensi pengembalian serta periode pengembalian yang dilakukan oleh para pedagang belum menjadi pertimbangan yang diperhitungkan oleh para para pedagang dalam melakukan pengajuan kredit. Hal ini terlihat pada pernyataan ke-19, ke-21, ke-23 dan ke-24 yang menjawab Sangat tidak Setuju di atas $50 \%$. Sedangkan pernyataan ke-20 pada umumnya dijawab dengan Sangat tidak Setuju sebesar 47,62\% yang masih dominan dibandingkan jawaban lain. Pernyataan ke-22 dijawab dengan Sangat tidak Setuju sebesar 47,62 yang juga masih dominan dibandingkan jawaban lainnya. Indikator-indikator mengenai Jangka Waktu pengembalian pinjaman ini seharusnya dapat dijadikan sebagai pertimbangan, namun pada umumnya para pedagang kurang memahami demikian. Ratarata yang paling rendah adalah pernyataan ke-21 dan pernyataan ke-24 sebesar 1,43.

Variabel dependen dalam hal ini bagaimana suatu pengajuan kredit pada akhirnya 
diputuskan oleh para pedagang dengan berbagai pertimbangan dapat dilihat pada pernyataan ke25 sampai ke-35. Pada umumnya jawaban para pedagang adalah Sangat Setuju, seperti pada pernyataan ke-25, ke-28, ke-29, ke-30, ke-31, ke-32, ke-33, ke-34 dan ke-35 yang menjawab Sangat Setuju paling tidak sebesar $50 \%$. Sedangkan pernyataan ke-26 dijawab dengan Sangat Setuju sebesar 45,24 oleh responden, pernyataan ke-27 dijawab Sangat Setuju dan Setuju masing-masing sebesar $42,86 \%$ dan $50 \%$. Hal ini menunjukkan bahwa variabel Keputusan Pengajuan Kredit menggunakan berbagai pertimbangan yang berhubungan dengan keputusan tersebut. Rata-rata yang paling besar adalah pernyataan ke-29 sebesar 4,57 .

Hasil pengujian Validitas data.

Sebelum diuji lebih lanjut, data yang diperoleh terlebih dahulu diuji kualitasnya, yaitu validitas dan reliabilitas data.

Tabel 8 Uji Validitas data

\begin{tabular}{|l|r|r|l|}
\hline No Pernyataan & Nilai Korelasi & Probabilitas & Keterangan \\
\hline Pernyataan 1 & 0,295 & 0,058 & valid \\
\hline Pernyataan 2 & 0,421 & 0,006 & valid \\
\hline Pernyataan 3 & 0,550 & 0,000 & valid \\
\hline Pernyataan 4 & 0,397 & 0,009 & valid \\
\hline Pernyataan 5 & 0,520 & 0,000 & valid \\
\hline Pernyataan 6 & 0,428 & 0,005 & valid \\
\hline Pernyataan 7 & 0,560 & 0,000 & valid \\
\hline Pernyataan 8 & 0,539 & 0,000 & valid \\
\hline Pernyataan 9 & 0,689 & 0,000 & valid \\
\hline Pernyataan 10 & 0,481 & 0,001 & valid \\
\hline Pernyataan 11 & 0,731 & 0,000 & valid \\
\hline Pernyataan 12 & 0,531 & 0,000 & valid \\
\hline Pernyataan 13 & 0,208 & 0,187 & valid \\
\hline Pernyataan 14 & 0,102 & 0,519 & valid \\
\hline Pernyataan 15 & 0,362 & 0,019 & valid \\
\hline Pernyataan 16 & 0,088 & 0,578 & valid \\
\hline Pernyataan 17 & 0,095 & 0,549 & valid \\
\hline Pernyataan 18 & $-0,109$ & 0,491 & tidak valid \\
\hline Pernyataan 19 & 0,403 & 0,008 & valid \\
\hline Pernyataan 20 & $-0,074$ & 0,640 & tidak valid \\
\hline Pernyataan 21 & 0,260 & 0,097 & valid \\
\hline Pernyataan 22 & $-0,074$ & 0,640 & tidak valid \\
\hline Pernyataan 23 & 0,088 & 0,578 & valid \\
\hline Pernyataan 24 & 0,362 & 0,019 & valid \\
\hline Pernyataan 25 & 0,023 & 0,887 & valid \\
\hline Pernyataan 26 & 0,333 & 0,031 & valid \\
\hline Pernyataan 27 & 0,237 & 0,130 & valid \\
\hline Pernyataan 28 & 0,371 & 0,016 & valid \\
\hline Pernyataan 29 & 0,000 & valid \\
\hline Pernyataan 30 & valid \\
\hline Pernyataan 31 & 000 & valid \\
\hline Pernyataan 32 & valid \\
\hline
\end{tabular}

\begin{tabular}{|l|l|l|l|} 
Pernyataan 33 & 0,689 & 0,000 & valid \\
\hline Pernyataan 34 & 0,481 & 0,001 & valid \\
\hline Pernyataan 35 & 0,731 & 0,000 & valid \\
\hline Pernyataan 36 & 0,531 & 0,000 & valid \\
\hline
\end{tabular}

Berdasarkan tabel uji validitas data tersebut di atas, ada 3 pernyataan yang tidak valid, yaitu pernyataan ke-18, ke-20 dan ke-22. Oleh karena itu, ketiga data tersebut tidak diikutsertakan pada uji-uji selanjutnya.

Hasil Uji Reliabilitas data

Pengujian selanjutnya adalah menguji kehandalan data-data yang sudah terkumpul, meliputi konsistensi dan kestabilan jawabanjawaban yang sudah dibuat terhadap suatu pernyataan.

\section{Tabel 9 Hasil Uji Reliablitias Data}

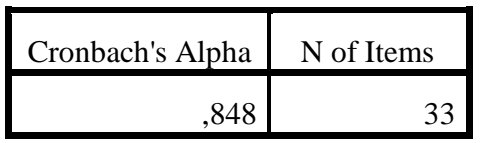

Dari tabel tersebut di atas menunjukkan hasil uji reliabilitas bahwa nilai Cronbach's Alpha adalah sebesar 0,848 (lebih besar dari 0,6), dengan jumlah item yang diuji sebanyak 33 item pernyataan maka instrumen yang diuji tersebut reliabel (dapat diandalkan).

\section{Pengujian Asumsi Klasik}

Pengujian asumsi klasik yang digunakan pada penelitian ini adalah Uji Normalitas, Uji Multikolinieritas dan Uji Heteroskedasitas.

Uji normalitas, dilakukan dengan one sample kolmogorov smirnov dan di tambah dengan Normal P-Plot of regression standardized residual

Tabel 10 One-Sample Kolmogorov-Smirnov Test

\begin{tabular}{|l|l|r|}
\hline \multicolumn{2}{|l|}{} & $\begin{array}{c}\text { Unstandardize } \\
\text { d Residual }\end{array}$ \\
\hline N & 42 \\
\hline \multirow{2}{*}{ Normal Parameters ${ }^{\text {a,b }}$} & Mean &, 0000000 \\
\cline { 2 - 3 } & Std. Deviation & 1,03838397 \\
\hline \multirow{3}{*}{ Most Extreme Differences } & Absolute &, 128 \\
\cline { 2 - 3 } & Positive &, 128 \\
\cline { 2 - 3 } & Negative &,- 119 \\
\hline Kolmogorov-Smirnov Z &, 830 \\
\hline Asymp. Sig. (2-tailed) &, 496 \\
\hline a. Test distribution is Normal. \\
\hline b. Calculated from data. \\
\hline
\end{tabular}

Berdasarkan tabel 10, nilai Asymp. Sig. (2tailed) sebesar 0,496 melebihi 0,05 maka data 
tersebut dinyatakan sudah terdistribusi secara normal.

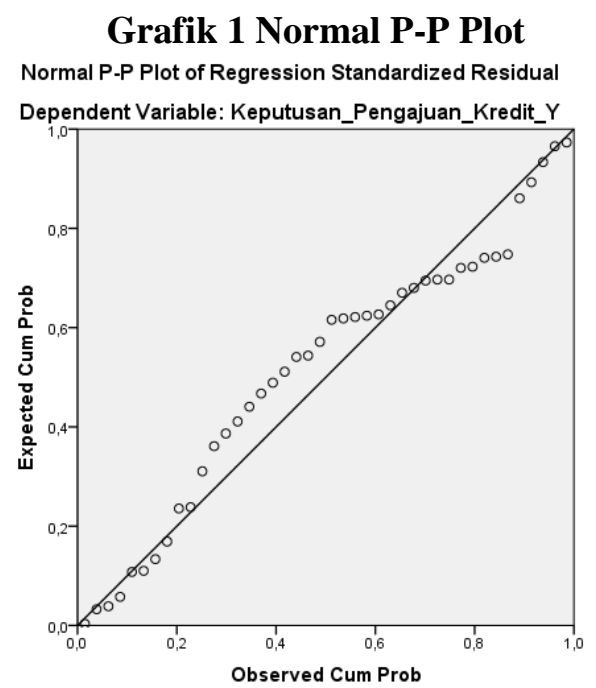

Begitu juga dengan menggunakan grafik P-P Plot dapat dilihat bahwa data telah berdistrisbusi normal karena penyebaran titik-titik searah dengan mengikuti garis diagonal.

Tabel 11 Uji Multikolinieritas

\begin{tabular}{|ll|r|r|}
\hline \multirow{2}{*}{$\mathrm{T}$} & \multicolumn{2}{|c|}{ Collinearity Statistics } \\
\cline { 3 - 4 } & & Tolerance & VIF \\
\hline \multirow{4}{*}{1} & (Constant) & & \\
\cline { 2 - 4 } & Pertimbangan_Irrasional_X & & \\
& Pertimbangan_Rasional_X &, 980 & 1,020 \\
& &, 980 & 1,020 \\
\hline
\end{tabular}

Berdasarkan tabel 11 dapat ditunjukkan bahwa variabel Pertimbangan Irrasional $\left(\mathrm{X}_{1}\right)$ dengan variabel Pertimbangan Rasional $\left(\mathrm{X}_{2}\right)$ menunjukkan nilai tolerance sebesar 0,980 (lebih besar dari 0,10) dan VIF sebesar 1,20 (lebih kecil dari 10), maka kedua variabel independen tersebut dinyatakan bebas multikolinearitas.

\section{Gambar 1 Statistik Scatterplot}

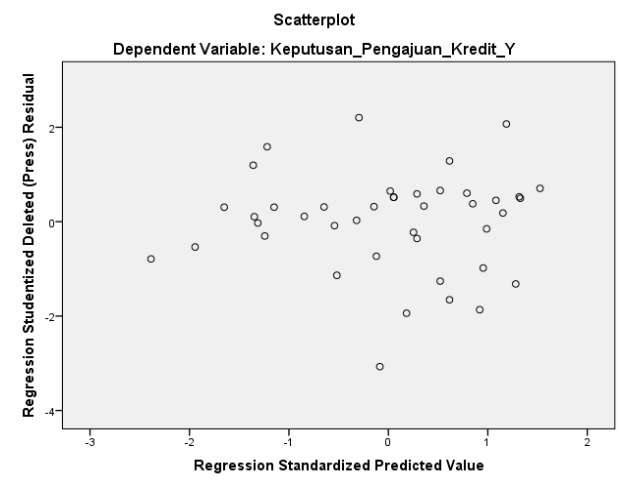

Dari gambar tersebut dapat dijelaskan bahwa titik-titik tersebut menyebar secara acak di sekitar atas dan di bawah angka nol pada sumbu Y. Maka dapat disimpulkan bahwa data telah memenuhi syarat yang ditentukan, sehingga dinyatakan terbebas dari heteroskedastisitas.

\section{Uji Hipotesis}

Analisis Regresi Berganda

Tabel 12 Hasil Analisis Regresi Linier Berganda

\begin{tabular}{|c|c|c|c|c|c|c|}
\hline \multirow{2}{*}{\multicolumn{2}{|c|}{ Model }} & \multicolumn{2}{|c|}{$\begin{array}{l}\text { Unstandardized } \\
\text { Coefficients }\end{array}$} & \multirow{2}{*}{$\begin{array}{c}\text { Standardized } \\
\text { Coefficients } \\
\text { Beta }\end{array}$} & \multirow[t]{2}{*}{$\mathrm{t}$} & \multirow[t]{2}{*}{ Sig } \\
\hline & & B & Std. Error & & & \\
\hline \multirow{3}{*}{1} & (Constant) & 5,068 & 2,143 & & 2,365 & $\begin{array}{r}, 02 \\
3\end{array}$ \\
\hline & $\begin{array}{l}\text { Pertimban } \\
\text { gan_Irrasio } \\
\text { nal_ } X_{1}\end{array}$ & ,927 & ,039 & ,976 & 23,841 & $\begin{array}{r}, 00 \\
0\end{array}$ \\
\hline & $\begin{array}{l}\text { Pertimban } \\
\text { gan_Rasio } \\
\text { nal_X }\end{array}$ &,- 139 & ,059 &,- 096 & $-2,350$ & $\begin{array}{r}, 02 \\
4\end{array}$ \\
\hline
\end{tabular}

Berdasarkan tabel tersebut di atas, diperoleh persamaan regresi sebagai berikut:

$$
Y=5,068+0,927 X_{1}-0,139 X_{2}+\varepsilon
$$

Berdasarkan persamaan tersebut, nilai konstanta diperoleh sebesar 5,068 yang berarti bahwa jika semua variabel independen bernilai 0, maka Keputusan Pengajuan Kredit sebesar 5,068 satuan. Kenaikan pada faktor-faktor pertimbangan Irasional sebesar 1 satuan akan mengakibatkan kenaikan pada Keputusan Pengajuan Kredit sebesar 0,927 satuan dengan asumsi variabel lain tetap. Sedangkan kenaikan pada faktor-faktor pertimbangan Rasional sebesar 1 satuan akan mengakibatkan penurunan pada Keputusan Pengajuan Kredit sebesar 0,139 satuan dengan asumsi variabel lain tetap.

\section{Uji Koefisien Determinasi}

\section{Tabel 13 Hasil Uji Koefisien Determinasi}

\begin{tabular}{|c|c|c|c|c|c|}
\hline \multirow{2}{*}{$\frac{\bar{d}}{\sum^{0}}$} & \multirow{2}{*}{$\mathrm{R}$} & \multirow{2}{*}{$\begin{array}{c}\mathrm{R} \\
\text { Square }\end{array}$} & \multirow{2}{*}{$\begin{array}{l}\text { Adjusted R } \\
\text { Square }\end{array}$} & \multirow{2}{*}{$\begin{array}{l}\text { Std. Error } \\
\text { of the } \\
\text { Estimate }\end{array}$} & $\begin{array}{l}\text { Durbin- } \\
\text { Watson }\end{array}$ \\
\hline & & & & & $\begin{array}{c}\text { R Square } \\
\text { Change }\end{array}$ \\
\hline 1 &, $967^{\mathrm{a}}$ & ,936 & ,933 & 1,06468 & ,936 \\
\hline
\end{tabular}


Berdasarkan tabel tersebut di atas,menunjukkan nilai Adjusted $R$-Square sebesar 0,933 menunjukkan bahwa Variabel Dependen dapat dijelaskan oleh variabel independen sebesar 93,33\%.

\section{Uji Parsial (Uji t)}

Berdasarkan tabel 12 , nilai Signifikansi variabel $\mathrm{X}_{1}$ sebesar 0,000 yaitu lebih kecil dari 0,05. Maka $\mathrm{HO}_{1}$ ditolak atau $\mathrm{Ha}_{1}$ diterima artinya bahwa Pertimbangan-pertimbangan Irrasional secara parsial berpengaruh positif signifikan terhadap Keputusan Pengajuan Kredit. Sedangkan nilai Signifikansi variabel $\mathrm{X}_{2}$ sebesar 0,024 yang juga lebih kecil dari 0,05 menunjukkan bahwa $\mathrm{HO}_{2}$ ditolak atau $\mathrm{Ha}_{2}$ diterima sehingga Pertimbangan-pertimbangan Rasional secara parsial berpengaruh negatif signifikan terhadap Keputusan Pengajuan Kredit.

\section{Uji Simultan (Uji F)}

Tabel 14 Hasil Uji F

\begin{tabular}{|c|c|c|c|c|c|}
\hline \multicolumn{6}{|c|}{ ANOVA $^{\mathrm{a}}$} \\
\hline Model & Sum of Squares & df & $\begin{array}{l}\text { Mean } \\
\text { Square }\end{array}$ & $\mathrm{F}$ & Sig. \\
\hline Regressio & 645,411 & 2 & 322,706 & 284 , & ,00 \\
\hline $\mathrm{n}$ & & & & 689 & $0^{\mathrm{b}}$ \\
\hline 1 Residual & 44,208 & 39 & 1,134 & & \\
\hline 「otal & 689,619 & 41 & & & \\
\hline
\end{tabular}

a. Dependent Variable: Keputusan_Pengajuan_Kredit_Y

b. Predictors: (Constant), Pertimbangan_Rasional_ $\mathrm{X}_{2}$,

Pertimbangan_Irrasional_ $\mathrm{X}_{1}$

Berdasarkan tabel 14 tersebut di atas, menunjukkan nilai signifikansi sebesar 0,000 yaitu lebih kecil dari 0,05 yang berarti bahwa Pertimbangan-pertimbangan Irrasional dan Rasional secara simultan mempengaruhi Keputusan Pengajuan Kredit.

\section{Uji Variabel Pemoderasi}

Tabel 15. Uji Variabel Pemoderasi

\begin{tabular}{|c|c|c|c|c|c|}
\hline \multirow{2}{*}{ Model } & \multicolumn{2}{|c|}{$\begin{array}{c}\text { Unstandardized } \\
\text { Coefficients }\end{array}$} & \multirow[t]{2}{*}{ 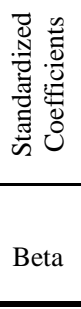 } & \multirow[t]{2}{*}{$\mathrm{t}$} & \multirow[t]{2}{*}{ Sig. } \\
\hline & B & $\begin{array}{l}\text { Std. } \\
\text { Error }\end{array}$ & & & \\
\hline (Constant) & 43,070 & 25,722 & & 1,674 & , 102 \\
\hline $\begin{array}{l}\text { Pertimbangan } \\
\text { _Irasional_X1 }\end{array}$ & 1,096 &, 120 & 1,154 & 9,103 & ,000 \\
\hline $\begin{array}{l}\text { Pertımbangan } \\
\text { _Rasional_X2 }\end{array}$ & ,478 & ,420 & ,332 & 1,138 & ,262 \\
\hline Pemoderasi & $-8,446$ & 5,698 &,- 489 & $-1,482$ & ,146 \\
\hline
\end{tabular}

Dari tabel tersebut di atas, dapat disimpulkan bahwa para pedagang belum melibatkan pertimbangan-pertimbangan rasional untuk menggantikan pertimbangan-pertimbangan Irrasional dalam membuat keputusan pengajuan kredit. Hal ini dapat dilihat pada nilai signifikansi variabel pemoderasi sebesar 0,146 atau lebih besar dari 0,05 , artinya tidak signifikan.

\section{KESIMPULAN}

Seluruh pertimbangan Irrasional maupun Rasional berpengaruh signifikan terhadap Keputusan Pengajuan Kredit oleh para Pedagang Pasar di Pasar Tradisional Nagoya Baru Batam, namun belum menjadikan pertimbangan Rasioanal sebagai faktor yang memperlemah pertimbangan Irrasional.

\section{UCAPAN TERIMAKASIH}

Ucapan terima kasih kepada Dikti yang sudah mendanai seluruh proses penelitian ini dan kepada LPPM Universitas Universal Batam atas segala dukungan yang telah diberikan.

\section{DAFTAR PUSTAKA}

\section{al, A. Q. (2017, 5). Rentenir dan pedagang} muslim (Sebuah Studi tentang Interaksi Sosial di Pasar Legi Kotagede). Retrieved from http://digilib.iain-palangkaraya.ac.id: http://digilib.iain-

palangkaraya.ac.id/1104/1/SKRIPSI\%20D ITA\%20AULIA\%20$\% 201202120201 . p d f$ 
Bahasa, B. P. (2016). KBBI Daring. Jakarta, DKI, Indonesia.

Djojohadikusumo, S. (1998). Kredit Rakyat di Masa Depresi. Jakarta: LP3S.

Hamka, A. A. (2010). Tugas I. J. Indones. Appl. Econ., vol. 4, 58-70.

Indonesia, Republik. (2014). UNDANGUNDANG REPUBLIK INDONESIA NOMOR 7 TAHUN 2014. Jakarta: Republik Indonesia.

Kartono, D. T. (2004). PASAR MODAL TRADISIONAL ( Analisis Sosiologi Ekonomi terhadap Rentenir). Jurnal Sosiologi, DILEMA, 1-9.

Kasmir. (2014). Pengantar Manajemen Keuangan. Jakarta: Prenadamedia Gro.

Moleong, L. J. (2007). Metode Penelitian

Kualitatif. Bandung: Remaja

Rosdaakarya.

Situmorang, B. (2018). KEBERADAAN

RENTENIR DI ANTARA PEDAGANG

PASAR DENGAN. Seminara Nasional:

Tantangan dan Peluang Pendidikan di

Era Baru (p. 7). Batam: Batam Publisher.

Suliyanto. (2006). Metode Riset Bisnis.

Yogyakarta: Andi.

Susilawati, R. (2016). Pola Hubungan Sosial antara Rentenir dengan Nasabahnya di Kelurahan. JOM FISIP, 1-14.

Sutojo, S. (2000). Dasar-dasar Pelayanan Prima. Jakarta: PT DamarMulia Pustaka.

Syafrini, D. (2014). NELAYAN VS

RENTENIR (Studi Ketergantungan

Nelayan terhadap Rentenir pada

Masyarakat Pesisir). J. Ilmu Sos.

Mamangan, vol. 1, no. 2, 54-67.
Y. Ahmad Erani. (2008). Ekonomi Kelembagaan (Definisi, Teori dan Strategi). Malang: Bayumedia Publishing. 